\title{
SEGMENTASI PELANGGAN \\ PADA BISNIS WEDDING ORGANIZER
}

\author{
Ina Melati \\ Jurusan Manajemen Universitas Bina Nusantara \\ ina.melati.ind@gmail.com
}

\begin{abstract}
Wedding is one of the most important and beautiful thing in a human life, they want that happen only once in their lifetime, that's why they aren't mind if they have to spend lot of money to have an unforgettable wedding. For some of Indonesian, wedding party is often considered as someone social status acknowledgement. Wedding party is the one of High Involvement service, that is when a consumer have spent a huge of money and they want the best service as a return. Through Ethnography, segmentation for a Wedding Organizer's consumer will be described very well and clearly, so that the best service will be delivered to the correct consumer.
\end{abstract}

Keywords: high involvement, segmentation, ethnography

\begin{abstract}
ABSTRAK
Pernikahan adalah salah satu momen terpenting dan terindah dalam kehidupan seseorang, mereka mengharapkan pesta pernikahan dilaksanakan sekali seumur hidupnya, Untuk itulah tidak jarang mereka mengeluarkan biaya yang jumlahnya tidak sedikit untuk menyelenggarakan pesta pernikahannya. Bagi sebagian besar masyarakat Indonesia, pesta pernikahan seringkali dianggap sebagai gambaran atau pengakuan terhadap status sosial seseorang. Pesta pernikahan dianggap sebagai sebuah kebutuhan yang bersifat High Involvement, di mana konsumen sudah mengeluarkan sejumlah dana yang cukup besar dan mereka menginginkan pelayanan dan hasil yang memuaskan juga. Melalui metode Etnografi, segmentasi bagi pelanggan Wedding Organizer dapat dilakukan secara jelas dan tepat sehingga pelayanan yang terbaik dapat diberikan kepada pihak yang tepat.
\end{abstract}

Kata kunci: keterlibatan tinggi, segmentasi, etnografi 


\section{PENDAHULUAN}

Kebanyakan masyarakat yang tinggal di perkotaan, menghabiskan sebagian besar waktunya untuk bekerja, sehingga mereka tidak memiliki banyak waktu luang untuk mengerjakan hal yang lain. Hari libur yang mereka miliki biasanya mereka manfaatkan untuk beristirahat. Pikiran akan bertambah ketika mereka ingin menyelenggarakan pesta pernikahan, selain tentu saja pekerjaan yang tidak mungkin ditinggalkan, pernikahan adalah sebuah pengalaman yang jelas saja baru bagi mereka, hampir bisa dipastikan mereka akan bingung untuk memulai dari mana, tidak terkecuali bagi orangorang yang sudah pernah mengalami sebelumnya, misalnya ketika mereka mengurusi pernikahan kakak, adik, anggota keluarga besar lainnya, ataupun mereka pernah mengalaminya sendiri. Karena pada dasarnya mereka adalah individu-individu yang memiliki kemauan dan kemampuan yang berbeda satu sama lain, belum tentu pola yang sama bisa diterapkan pada individu yang lain, dan tidak jarang hal tersebut menimbulkan perselisihan di antara Calon Pengantin Pria (CPP) dan Calon Pengantin Wanita (CPW), antara orang tua kedua belah pihak, atau bahkan melibatkan keluarga besar kedua belah pihak, seperti pernyataan yang sering dilontarkan oleh banyak pihak di Indonesia, "Apabila orang Indonesia menikah bukan hanya menikah dengan pasangannya saja, tetapi juga menikah dengan keluarga besarnya”.

Untuk itulah jasa Wedding Organizer menjadi sangat dibutuhkan saat ini, di mana mereka tidak hanya berperan sebagai penyumbang ide dan konsep pernikahan, pengatur persiapan seluruh rangkaian pernikahan, dan menjamin bahwa seluruh proses pernikahan berjalan dengan sesuai dengan yang diinginkan oleh konsumen, mereka juga dituntut untuk menjadi mediator diantara keluarga kedua belah pihak. Pihak Wedding Organizer paham betul bahwa kelancaran sebuah proses pernikahan, bergantung kepada mereka. Oleh sebab itu, banyak Wedding Organizer yang mematok biaya yang cukup tinggi untuk pelayanan mereka. Beberapa di antara mereka menghargai jasa mereka sebesar $10 \%$ dari total rangkaian acara. Sebagian lagi menghargai jasanya sebesar $15 \%$, bahkan ada yang mematok hingga $20 \%$ dari total rangkaian acara untuk menyelenggarakan sebuah pesta pernikahan sehingga dari situ bisa dilihat bahwa konsumen mengeluarkan biaya yang sangat besar, terlebih lagi bila mereka menggunakan jasa Wedding Organizer.

Pada teori High Involvement, dijelaskan bahwa semakin mahal sebuah barang, maka semakin tinggi pula tingkat pelayanan yang diharapkan oleh konsumennya, dan teori ini jelas berlaku dalam bisnis Wedding Organizer. Namun, seringkali Wedding Organizer lupa atau tidak terlalu peduli akan hal tersebut sehingga menimbulkan banyak kekecewaan pada konsumennya. Beberapa hal yang kemudian menjadi permasalahan berkaitan dengan hal tersebut. Wedding Organizer sering kali menyajikan pelayanan yang sama antara satu pelanggan dengan pelanggan yang lain. Hal yang membedakan biasanya hanya terlihat pada jumlah dan macam item/produknya saja karena mereka beranggapan bahwa semua konsumen berhak mendapatkan pelayanan yang sama.

Karena kesamaan pelayanan yang diberikan oleh Wedding Organizer, membuat konsumen yang membayar dengan Rupiah yang lebih besar merasa kurang puas karena apa yang mereka dapatkan ternyata sama saja dengan mereka yang membayar lebih sedikit dari mereka. Dengan kata lain, Wedding Organizer kurang bisa menyajikan pelayanan yang maksimal bagi masing-masing konsumennya. Oleh sebab itu, sepertinya Wedding Organizer perlu melakukan segmentasi bagi pelanggannya. Tujuannya adalah untuk memberikan pelayanan yang maksimal bagi konsumen yang akan melangsungkan pernikahan dan memerlukan jasa Wedding Organizer. Diharapkan juga bisa lebih meningkatkan kepuasan bagi masing-masing pelanggannya karena mereka merasa apa yang mereka keluarkan sepadan dengan yang mereka dapatkan. Hal tersebut akan menimbulkan dampak yang sangat baik bagi Wedding Organizer, mereka akan dipandang sebagai pihak yang sangat dibutuhkan bagi konsumen yang akan melangsungkan pernikahannya. 
Segmentasi bisa dilakukan melalui beragam cara, salah satunya adalah melalui Metode Etnografi. Etnografi akan membawa Wedding Organizer kepada konsumennya dengan lebih dekat lagi, Wedding Organizer akan bisa mengenal konsumennya lebih jauh lagi sehingga kemudian mereka bisa mengelompokkan konsumen tersebut berdasarkan kelompok-kelompok tertentu. Selanjutnya, apabila mereka mendapatkan konsumen-konsumen baru, mereka bisa memasukkan mereka ke dalam kelompok-kelompok tersebut, dan memberikan pelayanan yang sesuai bagi mereka, sesuai dengan kelompoknya masing-masing.

\section{METODE PENELITIAN}

\section{Etnografi}

Berasal dari antropologi, etnografi adalah metode riset yang menggunakan observasi langsung terhadap kegiatan manusia dalam konteks social dan budaya sehari-hari. Berdasarkan tulisan Maulana (2007), definisi dari ethnografi adalah suatu studi atau riset tentang perilaku masyarakat atau konsumen yang dipelajari langsung dari habitatnya atau dari lingkungan naturalnya. Seperti pernyataan Arnould (2001), profesor marketing dari University of Nebraska, "Etnography is a way to get up close and personal with consumers". Konsumen dipelajari di tempat ia tinggal, di tempat bekerja, bagaimana perilakunya saat berbelanja, saat bergaul dengan rekan-rekannya dan lain-lain.

Melalui etnografi peneliti akan mendapatkan unspoken needs dari konsumen, di mana banyak sekali kebutuhan konsumen yang tidak dapat terucap begitu saja dari mereka dan tidak bisa disampaikan secara langsung ke perusahaan. Selain itu, melalui etnografi pula akan didapatkan "wishing list" dari konsumen. Berdasarkan "wishing list” tersebut, perusahaan mendapatkan banyak masukan untuk perbaikan dan pengembangan terhadap inovasi-inovasi yang dibuat oleh perusahaan. Masih menurut Maulana (2007), etnografi mengubah perspektif pemasar membawa outside view (konsumen) to the inside (perusahaan).

\section{HASIL DAN PEMBAHASAN}

Definisi segmentasi adalah suatu proses membagi pemasaran produk berdasarkan sasaran pelanggan, di mana segementasi bertujuan untuk membagi-bagi pasar sehingga pemasaran dapat memusatkan pada target tersebut, dan dapat mengenai sasaran keinginan konsumennya. Segmentasi pelanggan Wedding Organizer sebaiknya mengarah kepada status sosial tertentu yang memiliki perbedaan karakteristik karena sudah menjadi sifat manusia, di mana manusia yang memiliki status sosial yang tinggi biasanya menginginkan pelayanan yang terbaik, dan hal ini sering dijumpai di sebagian besar masyarakat Indonesia.

Dilihat dari karakteristik konsumen pengguna jasa Wedding Organizer berdasarkan status sosialnya secara keseluruhan, menurut Ina \& Mita (2009) dapat disegmentasikan sebagai berikut. Pertama, the Wedding Dream. Pada segmen ini, ide, bayangan, dan keinginan bentuk acara sudah dimiliki konsumen secara detail dan jelas. Bahkan ada beberapa konsumen yang telah membayangkan pesta pernikahan idamannya sedari kecil. Mereka benar-benar memberikan segala usaha untuk dapat mewujudkan pernikahan sesuai dengan keinginannya. Bahkan biayapun tidak dijadikan batasan selama dapat memberikan kepuasan hasil dari pernikahnnya. Dalam memilih sebuah WO, mereka saling mendiskusikan kelebihan dan kekurangan WO tersebut, mereka juga rajin mencari info dan mengadakan dengan pendapat dengan orang-orang yang sudah terlebih dahulu menggunakan sebuah WO, melalui metode etnografi didapatkan insight konsumen sebagai berikut: "Yah ada enaknya juga 
sih, kita jadi tau banget apa yang mereka pengen, karena mereka ngejelasinnya detail buanget, tapi ya namanya WO ya musti siap sedia ditelponin sama mereka barang setengah jam sekali karena tibatiba mereka punya ide lagi untuk nambah ini dan itu, katanya sih biar semakin unik”.

Kedua, the Socialite. Konsumen yang termasuk ke dalam tipe ini adalah golongan masyarakat yang memiliki anggaran lebih pada sector keuangan pribadinya melebihi batas normal masyarakat pada umumnya, konsumen pada tipe ini biasanya tidak memntingkan masalah anggaran yang dibutuhkan ataupun besarnya dana yang harus dikeluarkan untuk sebuah perhelatan pernikahan yang sudah barang tentu diselenggarakan dengan sangat mewah dan elegan. Seperti kutipan narasumber berikut ini, "Kalo Mimi KD (Krisdayanti) mah enak, biasanya dia bilang gini, Yah terserah ajalah, baiknya gimana, aku mah nurut ajah, yang penting bagus”.

Ketiga, the Worcaholic Couple. Tipe konsumen ini banyak terdapat di kota-kota besar, umumnya mereka adalah masyarakat usia produktif dan sedang dalam tahap giat mencari uang. Oleh karenanya, mereka termasuk individu yang banyak menghabiskan waktunya di kantor. Mereka tidak memiliki banyak waktu untuk mencari informasi-informasi penting seputar pernikahan seperti misalnya gedung yang baik, catering yang enak, tim dokumentasi yang bonafit, rias pengantin yang anggun, dan sebagainya. Mereka hanya perlu mengajukan hal-hal yang mereka inginkan pada pihak WO, kemudian pihak WO mengajukan beberapa alternatif yang kira-kira akan disukai dan kemudian dipilih oleh calon pengantin, hingga pada akhirnya bisa terwujud sebuah pesta pernikahan yang memuaskan semua pihak. Melalui etnografi, didapatkan insight konsumen sebagai berikut: "Kebanyakan yang menyewa kita sih eksekutif-eksekutif muda, biasanya mereka udah repot banget sama kerjaannya, sebenernya mereka pengennya yang simpel aja, tapi biasa deh orang tuakan gak bisa yang simple-simpel, makanya yang ribet-ribet kayak gitu diserahin ke kita, mereka tau beres aja, kita kirim report tiap minggu".

Keempat, the "No Idea at All" Couple. Kekhawatiran adalah salah satu faktor utama yang membuat mereka memutuskan untuk menggunakan jasa Wedding Organizer. Kekhawatiran tersebut timbul karena mereka tidak tahu apa-apa mengenai detail pernikahan. Hal tersebut bisa disebabkan oleh banyak factor, misalnya tidak memiliki banyak rekan yang bisa dimintai saran dan pertimbangan, baru saja pindah dari kota kecil ke kota besar, dan sebagainya. Oleh karena itu, ketika mereka mengetahui bahwa ada pihak-pihak yang bisa membantu mereka, mereka akan memilih alternatif tersebut dibandingkan jika mereka bersusah payah mencari segala sesuatunya di tengah minimnya informasi yang mereka miliki. Belum lagi adat istiadat dan budaya di Indonesia yang beragam, tetapi sepertinya masih wajib dilakukan sehingga mereka harus bersama orang yang tepat apabila tidak mau dianggap salah atau melanggar adat istiadat dan budaya tersebut. Seperti kutipan salah seorang konsumen berikut: "ya aku sih mikirnya daripada ngurus ini itu yang aku juga gk ngerti, ditambah lagi aku gk pede ngelakuinnya sendiri, takutnya hasilnya gak sesuai bayangan”.

Kelima, the Wishy - Washy Couple. Konsumen jenis ini adalah konsumen yang seringkali membuat kru mereka sedikit kewalahan. Dikarenakan mereka tidak mampu mendeskripsikan keinginannya sendiri secara baik dan tepat sehingga terkadang Wedding Organizer menjadi lebih bingung untuk mewujudkan dan mengimplementasikannya pada acara pernikahan. Mereka juga kerap kali merubah segala macam detail yang sudah disepakati. Hal itu terjadi dikarenakan mereka terpengaruh oleh media-media yang ada di sekitarnya, misalnya majalah, website, tabloid, TV, dan lain lain. Pihak Wedding Organizer juga kerap kali dibuat tidak berdaya dengan perubahan-perubahan signifikan yang terjadi karena pemangku hajat sering mendapatkan inspirasi mendadak setelah melihat pesta pernikahan orang lain. Seperti yang tergambar dalam insight seorang konsumen berikut ini: "Wah kadang-kadang pusing, ada-ada aja deh yang berubah misalnya kemaren baru aja liat nikahannya Christian Sugiono waktu di resepsi, tiba-tiba dia telepon pengen baju yang kayak gitu juga, padahal konsepnya udah jelas beskap bukan duta besar, haduh kalo udah gitu mah kita bisanya cuma, oh iya oh iya aja sambil senyum-senyum basi di telepon gitu deh”. 
Keenam, the Familiar Faces Couple. Konsumen pada segmen ini adalah konsumen yang sudah sangat tahu dan mengenal tentang seluk beluk sebuah WO tertentu, misalnya saja keluarga besar mereka sudah turun temurun menggunakan WO tersebut, dan terbukti selalu sukses dalam penyelenggaraannya. Jadi, keputusan mereka untuk menggunakan WO lebih dikarenakan adanya pengaruh yang sangat besar dari orang-orang terdekatnya. Seperti kutipan dari seorang pemilik WO berikut ini: "Dari kakaknya yang nomer satu juga sudah sama kita, sampai dia di bontot juga masih sama kita, mungkin karena keluarga mereka udah tau performance kita, makanya mereka jadi santai aja buat ngejalanin semuanya, orang udah kita beresin semua kok, pokoknya mereka tinggal santai duduk dipelaminan aja deh”.

Ketujuh, the Uncle Scoorage. Konsumen yang termasuk ke golongan ini sangat berhati-hati dalam mengatur budget pernikahannya. Meskipun mereka sangat terikat dan tergantung dengan minimnya budget yang dimiliki, tetapi mereka juga menyadari akan adanya kebutuhan untuk menggunakan WO. Oleh karena itu, mereka akan menghitung dengan cermat segala pengeluaran, mulai dari membuat budget sendiri hingga mencari vendor-vendor yang sesuai dengan budget nya sendiri sehingga bagi pihak Wedding Organizer mereka hanya diminta untuk menyusun acara dan mengkoordinasi vendor-vendor tersebut. Seperti petikan pernyataan dari sebuah pemilik Wedding Organizer berikut ini: “Ada juga yang menggunakan kita untuk masalah koordinasi saja, jadi mereka depens on budget banget, apa-apa mereka siapin sendiri, apa-apa mereka cari sendiri kayak vendorvendor gitu, yang sesuai dengan budget mereka deh pokoknya, sampe kotak seserahan juga mereka cari sendiri”.

Berdasarkan segmentasi di atas, Wedding Organizer dapat mengambil langkah-langkah selanjutnya secara tepat karena mereka sudah memiliki gambaran, kira-kira calon konsumen seperti apa sajakah yang akan menjadi konsumen mereka. Dalam hal ini, Wedding Organizer tidak dituntut untuk melakukan pembedaan pelayanan kepada setiap segmen, hanya saja mereka diharapkan bisa memberikan pleyanan yang tepat kepada segmen yang tetap. Dengan demikian, tidak ada pihak yang merasa dirugikan.

\section{SIMPULAN}

Berdasarkan segmentasi diatas, maka dapat disimpulkan bahwa setiap segmen memiliki perilaku dan karakteristik yang berbeda-beda sehingga diperlukan treatment khusus bagi tiap-tiap segmen, di mana treatment khusus yang bisa dilakukan Wedding Organizer untuk memuaskan konsumen pada tiap-tiap segmennya adalah sebagai berikut. Pertama, the Wedding Dream Couple. Karena konsumen jenis ini tergolong ke dalam konsumen yang pintar, pemilih dan perfeksionis, bahkan beberapa di antara mereka cenderung cerewet, maka perlu penempatan seorang personil terpercaya dari pihak Wedding Organizer yang cukup cekatan, pintar dan sabar. Personil tersebut dituntut untuk bisa mengerti setiap kemauan konsumen pada segmen ini; tidak cukup hanya mengerti, tetapi juga bisa mengimplementasikannya pada pesta pernikahan. Satu hal yang harus diketahui oleh Wedding Organizer, sehubungan dengan konsumen pada segmen ini adalah mereka tidak terlalu peduli terhadap pembengkakan budget yang sangat mungkin terjadi. Asalkan semuanya bisa terpenuhi pada pesta pernikahan mereka, pihak Wedding Organizer bisa memberikan pelayanan 24 jam sehari kepada mereka, dan sah saja apabila Wedding Organizer memasukkan pelayanan ini ke dalam proyeksi budgeting mereka.

Kedua, the Socialitte Couple. Pada segmen ini, pimpinan Wedding Organizer diharapkan muncul dan berinteraksi sesering mungkin dengan pemangku hajat karena kebanyakan pemangku hajat pada segmen ini adalah termasuk kalangan terpandang yang membutuhkan perhatian ekstra dan seringkali menginginkan interaksi yang intens dan secara langsung dengan pimpinan. Apabila interaksi sudah terjalin dengan cukup baik, biasanya mereka akan meyerahkan segala urusannya 
kepada asisten pribadinya, ajudannya atau orang-orang terpercaya lain di sekitar mereka. Sama seperti segmen My Wedding Dream Couple, Wedding Organizer bisa menambahkan fitur pelayanan 24 jam sehari kepada segmen ini dan menambahkan biaya pada proyeksi budgeting mereka. Ketiga, the Worcaholic Couple. Karena keterbatasan waktu yang mereka miliki, sepertinya akan lebih efektif jika Wedding Organizer memilih satu orang personil yang menjadi asisten khusus bagi Calon Mempelai Wanita, dan satu orang personil lagi yang bertugas menjadi asisten khusus Calon Mempelai Pria. Mengingat Wedding Organizer juga memiliki konsumen lain yang juga memerlukan perhatian khusus, sementara akan sulit sekali mencari waktu luang di antara kedua pasangan dan pihak Wedding Organizer, kedua asisten tersebut akan bertugas selama persiapan pernikahan hingga pesta pernikahan berlangsung. Asisten khusus tersebut misalnya bertugas untuk membawakan baju pengantin yang sudah jadi ke kantor CPW dan CPP untuk dicoba dan dilihat di mana kekurangannya, atau asisten pribadi tersebut diharapkan bisa mengingatkan CPW dan CPP waktu kunjungan ke perias untuk tes make up, dan sebagainya.

Keempat, the "No Idea at All" Couple. Segmen ini bisa dibilang sebagai segmen yang "mudah" karena mereka pada umumnya akan menuruti segala sesuatu yang ditawarkan oleh Wedding Organizer, mulai dari budgeting, konsep hingga vendor. Sebagian dari mereka berasal dari kelompok masyarakat bertaraf hidup cukup mampu sehingga mereka juga tidak terlalu mempermasalahkan biaya, hanya saja perbedaannya dengan My Wedding Dream Couple dan The Socialitte adalah mereka tidak terlalu banyak "reader" atau permintaan-permintaan yang aneh-aneh dan menyusahkan pihak Wedding Organizer sehingga Wedding Organizer tidak perlu menyediakan personil berkemampuan khusus untuk mereka. Kelima, the Wishy - Washy Couple. Satu hal yang wajib diingat oleh Wedding Organizer ketika mereka menangani konsumen pada segmen ini adalah mereka harus bisa sabar, waspada dan saklek, jangan sampai perubahan signifikan yang mereka ajukan akan merugikan pihak Wedding Organizer. Pelayanan khusus yang bisa diberikan adalah dengan pemberian tawaran, pilihan dan informasi-informasi yang bersifat saran dan masukan sehingga tidak menambah kebingungan mereka, tunjukkan sesuatu hal yang memang sesuai dan terbaik bagi mereka, pilihan dan informasi sebaiknya tidak lebih dari 3 buah referensi, dan semuanya harus mengacu pada kontrak awal yang sudah disepakati. Apabila perubahan yang mereka ajukan benar-benar signifikan, jangan ragu untuk mencantumkan biaya pada proyeksi budgeting mereka.

Keenam, the Familiar Faces Couple. Karena sudah terbiasa dengan sebuah Wedding Organizer tertentu, maka tidak sulit bagi Wedding Organizer untuk mengemban tugas dari mereka. Satu hal yang perlu diingat adalah mereka sudah melihat hasil yang terbaik dari performa yang sebelumnya jadi mereka tidak akan mentolerir kesalahan yang mungkin saja terjadi. Jadi, Wedding Organizer tidak boleh lengah dan menganggap enteng, mengingat segemen ini adalah segmen yang paling loyal, setia, sekaligus paling susah dicari. Pimpinan dan seluruh personal harus menempatkan posisi sebagai bagian dari keluarga besar mereka. Pelayanan khusus yang bisa diberikan bagi mereka adalah menjadi mediator bagi masalah-masalah di antara kedua belah pihak yang mungkin saja muncul, menjadi penasihat perkawinan bagi kedua belah pihak, atau bisa saja sebagai teman berbagai keluh kesah dan teman curhat. Wedding Organizer diharapkan bisa menjadi pihak yang tidak memihak dan menciptakan suasana nyaman karena sudah seperti keluarga biasanya Wedding Organizer melakukan semua hal itu dengan sukarela. Ketujuh, the Uncle Scoorage. Karena segmen ini adalah segmen yang begitu memperhitungkan masalah keuangan, sangat jeli dan pintar bersiasat, jadi Wedding Organizer dituntut untuk lebih pandai dan berhati-hati karena biasanya mereka akan mencatat secara mendetail hal-hal yang terucap dari pihak Wedding Organizer. Oleh sebab itu, Wedding Organizer perlu mengacu pada kontrak dan tidak mudah menyetujui apa yang mereka ajukan tanpa melihat kontrak atau berbicara terlebih dahulu dengan pimpinan. Tawar-menawar adalah ciri khas dari konsumen pada segmen ini, dan lebih teliti serta sedikit pelit, boleh menjadi pilihan sikap bagi Wedding Organizer. Pelayanan khusus yang bisa diberikan kepada mereka adalah penghitungan proyeksi budgeting yang paling efektif dan efisien juga mendetail sehingga mereka bisa menggunakannya sebagai acuan. 


\section{DAFTAR PUSTAKA}

Kotler, P., and Keller, K. (2006). Marketing management, $12^{\text {th }}$ ed., New Jersey: Prentice Hall.

Maulana, A. (2008). Insight via ethnography. Retrieved from http://amaliamaulana.com/2008/06/02/insight-via-ethnography.

Melati, I., dan Tiara, M. (2009). Consumer insight: Dinamika pemilihan sebuah wedding organizer. Tesis tidak diterbitkan, Jakarta: Program Pascasarjana, Universitas Bina Nusantara. 